\title{
MEMBANGUN GENERASI MELALUI PENDIDIKAN SEBAGAI INVESTASI MASA DEPAN
}

\author{
Oleh: \\ Harun Rasyid \\ PAUD FIP Universitas Negeri Yogyakarta \\ harun_pgpauduny@yahoo.com
}

\begin{abstract}
Abstrak
Untuk melahirkan manusia Indonesia yang unggul itu, diperlukan suatu arah kebijakan pembangunan yang memprioritaskan pendidikan sebagai investasi masa depan. Sebagai investasi masa depan bangsa, maka pendidikan harus dimulai sejak anak usia dini sebagai program yang berkelanjutan dan sistemik yang dikemas dalam dalam berbagai program kebijakan, yang dimulai dari pendidikan anak usia dini, pendidikan dasar, pendidikan menengah, sampai dengan pendidikan tinggi. Untuk menyukseskan program tersebut dibutuhkan berbagai perbaikan dalam hal kebijakan pendidikan untuk semua anak bangsa, peningkatan kualitas pendidik dan program pendidikan di Indonesia
\end{abstract}

Kata Kunci: Pendidikan, Anak Usia Dini

\section{Abstract}

Creating excellent Indonesian generation needs a developmental policy directed to prioritize education as our future investment. In the role of our nation's future investment, education must be started from early ages as a continue and systemic program in the form of various policy programs, started from education in early childhood, in elementary, primary, secondary up to university. To make it successful, many improvements in policy concerning education for the nation as well as quality enhancement from both educators and educational program in Indonesia are needed.

Keywords: education, early-aged children

PENDAHULUAN

Kemajuan suatu bangsa ditandai dengan majunya kesempatan memper-oleh pendidikan yang luas dan berkualitas bagi masyarakatnya. Pendidikan yang berkualitas dan dinikmati secara luas oleh setiap anggota masyarakat bangsa itu, termasuk anak usia dini merupakan usaha bangsa itu untuk memperoleh kualitas dirinya. Dengan kualitas diri yang diperoleh lewat pendidikan, (Tilaar, 1999:34) maka bangsa itu akan sanggup hidup secara tangguh dalam masyarakat dunia yang ditandai dengan kehidupan yang penuh dengan tantangan dan kompetisi secara ketat. Kehidupan yang kompetitif dan penuh tantangan itu memerlukan modal kemampuan manusia yang berkualitas. Kualitas sumber daya manusia masa kini menjadi kunci utama untuk meraih masa depan (Kompas, 2006), ter-masuk program pengembangan anak usia dini (Kompas,2007), sebagai langkah awal penyiapan kualitas sumber daya manusia. Mereka yang berkualitas akan mampu memprediksi apa yang terjadi di depan, dan merealisasikan apa yang menjadi kebutuhan di masa depan. Mereka pulalah yang kelak akan mampu memetik manfaat dan menikmati berbagai produk kehidupan paling maksimal. 
Dalam konteks manusia yang berkualitas dan memiliki keunggulan, maka keunggulan itu perlu dikenali dan dikembangkan sebagai nilai tambah. Keunggul-an sumber daya manusia Indonesia sebagai nilai tambah sangat dibutuhkan dalam menghadapi kehidupan yang kompetitif dan penuh tantangan. Manusia Indonesia yang unggul itu tidak hanya unggul otak dan trampil, tetapi juga unggul dalam komitmen, tabiat, perilaku, dan punya hatinurani terhadap rakyat (Kompas,19 Mei,2006), dan mencintai serta sangat dekat dengan seluruh rakyat. Untuk melahirkan manusia unggul itu, diperlukan suatu arah kebijakan pembangunan yang memprioritaskan pendidikan sebagai investasi masa depan. Sebagai investasi masa depan bangsa, maka pendidikan harus dimulai sejak anak usia dini sebagai program yang berkelanjutan dan sistemik yang dikemas dalam dalam berbagai program kebijakan, yang dimulai dari pendidikan anak usia dini, pendidikan dasar, pendidikan menengah, sampai dengan pendidikan tinggi. Untuk itu semua, diperlukan: a) arah dan substansi pendidikan yang jelas; b) keunggulan manusia sebagai investasi masa depan; c) redisain pendidikan di Indonesia; dan d) pendidikan untuk semua anak bangsa termasuk anak usia dini.

\section{a. Arah dan substansi pendidikan}

Pendidikan sebagai suatu investasi masa depan bagi masyarakat suatu bangsa, tidak hanya sekedar dinikmati dan didapatkan dalam kesempatan alakadarnya untuk bisa baca-tulis-hitung sebagai suatu pemerataan. Pendidikan yang didapatkan dan dinikmati itu, haruslah pendidikan yang berkualitas dan memiliki keunggulan, sehingga menjadi bekal hidup dalam menghadapi tanta-ngan gelobal yang keras dan kompetitif. Oleh karenanya pendidikan harus punya arah yang jelas dan substansinya tegas sebagai karakter bangsa Indonesia. Dalam konteks kejelasan arah suatu pendidikan akan dapat membawa peserta didik kepada kondisi tentang keseluruhan potensi yang dimilikinya. Keseluruhan potensi peserta didik harus menjadi titik tumpu dalam arah pendidik yang dikembangkan. Pendidikan tidak hanya diarahkan untuk menjadi manusia sebagai alat produksi, sebagaimana konsep kapitalis, untuk penguasaan iptek demi kelangsungan higemoni kekuasaan. Melainkan pendidikan harus dibawa kepada proses pembentukan manusia sutuhnya, sebagaimana dikatakan Mendiknas..."pendidikan tidak hanya menempatkan manusia sebagai alat produksi melainkan pendidikan sebagai proses pembentukan manusia seutuhnya" (Kom-pas,2005), dan wahana strategis pengembangan potensi individu (Depdiknas, 2006). Jadi, pendidikan harus bersifat menyeluruh dan imbang antara lahir batin.

Proses pembentukan manusia seutuhnya mengandung makna bahwa manusia itu tidak hanya memiliki jiwa dan raga yang bisa dikembangkan lewat pendidikan, melainkan ia memiliki fithrah yang juga harus dikembangkan. Mengabaikan pengembangan fithrah dalam proses pendidikan mengakibatkan rendahnya moral yang tercemin dalam perilaku emosional dan impulsif (Depdiknas,2000:3;2006:9). Perilaku emosional dan impulsif itu merupakan indikasi adanya aspek-aspek pokok yang terlupakan dalam proses pendidikan yang selama ini berlangsung. Aspek itu ialah fithrah sebagai ciri khusus manusia. Fithrah, yang merupakan potensi dasar manusia sebagai makhluk yang bermoral, makhluk yang berakhlak, dan makhluk yang sebaikbaiknya ciptaan (QS. At-Thin:4). Akhlak dan moral jika dilihat dari sifat dasar manusia, maka ia merupakan naluri ke arah kebaikan yang bersumber dari ajaran agama (Madjid, 1995: 176), dan cenderung untuk melakukan perbuatan baik (Purba, 2007), yang bermuara kepada Ibrahim 
(Abrahamic Religions). Konsep Abrahamic Religions ini meletakkan bahwa manusia itu dilahirkan dalam keadaan kesucian, yang terkenal dengan instilah fithrah atau potensi dasar. Konsep fithrah sebagai sifat dasar kesucian manusia ini, harus dinyatakan dalam sikapsikap yang suci dan baik kepada sesama manusia, yang dikondisikan berkembang atau diberdayakan (Purba, 2007). Sifat dasar yang dimiliki manusia itu merupakan bukti bahwa manusia itu sebagai makhluk yang hanif, yang memiliki dorongan naluriyah ke arah kebaikan dan kebenaran. Pusat dorongan hanif itu menurut Madjid (1995: 179) terdapat dalam diri manusia yang paling dalam dan paling murni, yang disebut hati atau nurani, potensi yang lurus (Sihab, 2000:284).

Konsep hanif, jika dihubungkan dengan teori pendidikan dan teori belajar, maka ia tergolong aliran progresivisme dan kognitif. Pandangan progresivisme menegaskan bahwa, manusia mempunyai potensi atau kemampuan-kemampuan yang dapat dikembangkan guna mengakumulasi pengetahuan dan pengalaman moral yang tertuju ke arah yang baik (Barnadib,1988:19-20; Papalia, 1986: 250), dan akan meningkat secara terus menerus. Jadi pendidikan itu harus diarahkan untuk mengembangkan manusia itu pada fithrahnya yang suci. Mengembangkan fithrah yang suci menurut (Madjid,1995:192) adalah mengembalikan manusia pada naturnya, sebagai cara untuk memperoleh pengetahuan (Sihab, 2000:291).

Kesucian atau fithrah yang dimiliki manusia, menurut Mendiknas (2005) dapat dikelompokkan menjadi empat jenis: ftihrah pikir, fithrah hati dan jiwa, fithrah rasa, dan fithrah raga. Keempat fithrah yang dimiliki manusia itu, jika dilihat dari sisi substansi pengembangan manusia adalah merupakan potensi yang dapat dikembangkan dan ditumbuhkan semaksimal mungkin sampai pada tahap yang optimal lewat pendidikan dan latihan. Pengembangan potensi yang optimal itu memungkinkan manusia menjadi manusia yang cerdas, mandiri, berbudi, berbudaya, dan berakhlak mulia, sekaligus, menurut (Aristiarini, 2006; Purba,2007) mudah beradaptasi dalam keragaman budaya. Potensi pikir manusia merupakan anugrah Allah yang sangat tinggi, sekaligus sebagai pembeda dengan makhluk lainnya, yang sanggup memahami dan menganalisis sesuatu (Sihab, 2000:292), mampu berpikir dengan menggunakan simbol (Papalia,1986:183).

Dengan potensi pikir atau fuad itu, manusia akan mampu berpikir dan memikirkan dirinya, lingkungan sekitarnya dan masyarakatnya dahulu, sekarang dan masa mendatang (QS. Al-Hasyr:18). Hal ini berarti bahwa manusia memiliki kemampuan berpikir jauh melampaui dirinya, lintas dimensi tempat dan waktu. Persoalannya adalah, kapankah potensi pikir manusia itu dapat dikembangkan dan ditumbuhkan? Jawabannya adalah terletak pada proses pendidikan yang harus dimulai sejak lahir sampai liang lahat, terutama pada masa anak usia dini.

Potensi pikir yang dimiliki manusia, mengharuskan ia berhadapan dengan tugas pokoknya di muka bumi sebagai makhluk yang bertanggungjawab atas terpeliharanya alam dan seluruh isinya. Ia dijuluki Allah sebagai khalifatullah di bumi (QS.Al-Baqarah:27). Sebagai khalifah ia juga harus memikirkan dirinya, masyarakatnya, dan lingkungannya. Ketika ia berpikir tentang bumi dan seluruh isinya agar tetap terpelihara dengan baik, maka ia memerlukan potensi lain yang mendampingi pikirannya. Potensi lain itu ialah hati dan jiwa. Potensi pikir yang bertugas memikirkan tentang sesuatu di luar dirinya sangat memerlukan pertimbangan hati dan jiwa secara matang, untuk dijadikan keputusan sebagai formulasi moral (Papalia, 1986:250), suatu perbuatan yang dilakukan. 
Hati dan jiwa bagi manusia merupakan alat potensial untuk mengukur baik buruknya suatu keputusan perbuatan. Ia juga sebagai alat pantau untuk mendeteksi dan memberikan kriteria tentang manfaat dan mudaratnya suatu keputusan perbuatan. Ia berfungsi sebagai alat potesnsial untuk membulak-balikkan suatu perbuatan yang akan diputuskan untuk dijadikan tindakan nyata, ia sebagai moral behavior (Papalia, 1986:254). Jadi keterkaitan pikiran dengan hati dan jiwa dalam suatu pertimbangan yang akan dijadikan keputusan suatu perbuatan, berjalan dan berfungsi secara bersamasama. Oleh karenanya, pendi-dikan secara substansial harus mengarah pada upaya yang jelas untuk mengem-bangkan dan menumbuhkan hati dan jiwa yang bersih sebagai landasan berpikir kreatif yang mengarah kepada perbuatan yang baik. Perbuatan yang memberi-kan manfaat bagi manusia dan lingkungannya merupakan nilai moral manusia.

Manusia yang memikirkan suatu perbuatan keputusan yang dilandasi oleh pertimbangan hati dan jiwa yang jernih, ia masih memerlukan suatu kedalaman akibat keputusan perbuatan itu, ialah rasa. Rasa berfungsi sebagai sesuatu yang sangat menentukan baik buruknya akibat dari perbuatan untuk dilakukan atau tidak dilakukan. Rasa merupakan bagian aspek ruhaniyah yang sangat dalam dan suci yang bersumber pada pikiran, hati dan jiwa manusia dalam berbagai situasi, Papalia (1986:251) ... that person would think and feel in a gaven situation. Rasa yang dimiliki manusia itu merupakan potensi dasar yang harus dibi-na, ditumbuhkan, dan dikembangkan terutama pada masa usia dini. Potensi rasa yang dibina dan dikembangkan sejak anak usia dini lewat pendidikan dan latihan akan memberikan kontribusi yang sangat bermakna dalam kehidupannya kelak di masa mendatang. Potensi rasa ini dapat mencakup: rasa aman, rasa percaya diri, rasa ingin tahu, rasa ingin dihargai dan menghargai, rasa mencintai dan dicintai, serta rasa kebersamaan dan kemanusiaan, Maslow (dalam Reodiger III,1986: 413). Potensi rasa, potensi hati dan jiwa, serta potensi pikir yang dimiliki manusia akan berfungsi bersama ketika manusia itu berpikir dan mempertimbangkan suatu keputusan untuk berbuat sesuatu. Ketiga potensi ini akan berdampak pada raga yang bertugas melaksanakan hasil olah pikir yang dilandasi oleh hati dan jiwa yang jernih, serta rasa yang dalam untuk tampil dalam performance dan perbuatan yang dilakukan, serta mengandung nilai moral yang tinggi.

Oleh karenanya, potensi rasa tersebut harus menjadi arah dan subsatansi pendidikan yang ditumbuhkan dan dikembangkan sejak anak usia dini, sehingga kelak menjadi manusia yang memiliki rasa yang dalam dan memiliki moral behavior. Hal ini sangat berguna untuk mempertimbangkan segala perbuatan yang baik berdasarkan pikiran, hati dan jiwa yang jernih. Muaranya adalah manusia yang berbudi dan berakhlak mulia, serta manusia yang bermoral tinggi.

Manusia itu secara substansial memiliki dua aspek pokok dalam menjalani hidup dan kehidupannya, kedua aspek itu ialah ruhaniah dan jasmaniah. Aspek ruhaniah meliputi pikir, hati dan jiwa, serta rasa. Sementara aspek jasmaniah ialah berupa jasad fisik yang tampak yang dapat diukur dalam gerak dan aktivitas. Dengan aspek ruhaniah dan jasmaniah yang dimiliki manusia itu, maka ia menjadi bisa hidup dan bisa menjalani kehidupannya di alam ini. Hal ini merupakan bukti empirik bahwa manusia itu berbeda dengan makhluk lainnya, yang tidak memiliki aspek ruhaniah (QS. As-Sajdah:9). Aspek jasmaniah bagi manusia merupakan potensi fisik yang sangat lengkap dan sempurna untuk melakukan suatu perbuatan atas perintah otak. Proses 
berpikir yang dilakukan otak yang dilandasi pertimbangan matang yang bersumber dari hati dan jiwa yang disertai ukuran rasa yang dalam, akan menjadi keputusan suatu perbuatan untuk dilakukan atau tidak dilakukan oleh aspek ragawi. Tindakan atas pertimba-ngan hati dan jiwa yang matang dapat diukur, dinilai dan dilihat dampaknya, melalui produk perbuatan yang diterima atau ditolak masyarakat.

Potensi ragawi pada manusia tidak serta merta dapat berfungsi secara bersama dalam waktu yang sama. Ia akan berfungsi secara bertahap sesuai dengan masa pertumbuhan dan perkembangannya (QS. Al-Insyiqak: 19). Sama halnya dengan potensi ruhaniah, ia akan berfungsi sesuai dengan pertumbuhan dan perkembangannya sejalan dengan usia kronologisnya. Oleh karena itu, pendidikan dan latihan harus mengarah pada pengembangan potensi ragawi sesuai tahapan-tahapannya (Piaget, 1986). Pendidikan juga harus didesain secara holistik dengan aspek ruhani sebagai fungsionalisasi seluruh potensi yang dimiliki manusia secara optimal yang berorientasi pada olah hati, pikir, rasa dan raga. Dalam konteks pengembangan sumber daya manusia melalui pendidikan dan latihan yang secara substansial diarahkan kepada pembinaan tumbuhkembangnya potensi dasar manusia, sekaligus merupakan pembentukan karakter bangsa yang sangat menentukan eksistensi bangsa itu di masa depan. Dengan pendidikan yang didesain untuk mengarahkan dan mengembangkan seluruh potensi peserta didik pada usia dini yang dilakukan sedini mungkin, akan terlahir pribadi-pribadi yang memiliki karakter kuat sebagai penerus bangsa. Oleh karena itu, bangsa ini akan dibawa dan ditentukan oleh pribadi-pribadi maupun individu-individu diantara anak bangsa yang berkarater unggul tersebut. Bertalian dengan konteks ini, Fasli Jalal (2006) menegaskan bahwa proses pembentukan karakter bangsa haruslah dimulai dari diri anak sejak masa tumbuh kembang di usia prasekolah. Untuk itu, perlu otoritas dan intervensi orang dewasa dalam memberdayakan dan mengembangkan seluruh potensi anak usia dini sebagai investasi masa depan. Keliru dalam mendidik anak usia dini akan berakibat fatal, dan menjadi gagallah pembentukan karakter bangsa itu. Kegagalan pembentukan karakter suatu bangsa lewat pendidikan akan ber-akibat fatal dan akan menuju kepada hancurnya bangsa dan negara itu sendiri.

\section{b. Keunggulan Manusia dalam Investasi Masa Depan}

Seperti telah dibahas pada bagian sebelumnya bahwa manusia memiliki aspek ruhani dan jasmani yang sempurna sebagai makhluk yang unggul (QS. At Tiin:4) dibanding dengan makhluk Allah lainnya. Keunggulan manusia sebagai makhluk individu dan sekaligus sebagi makhluk sosial yang memiliki potensi ruhaniah dan jasmaniah. Potensi-potensi yang dimiliki itu dapat dikembangkan dan ditumbuhkan secara optimal lewat pendidikan dan latihan sejak masa anak usia dini, sehingga memiliki keseimbangan keduanya. Manusia dengan jasmaninya dapat bekerja untuk memenuhi segala keperluan hidupnya. Untuk dapat bekerja, ia harus memiliki pengetahuan dan ketrampilan yang profesional dan keunggulan kompetitif, sehingga ia dapat eksis dan mempertahankan hidupnya dalam percaturan nasional, regional, dan global. Hidup dalam percaturan global memerlukan bekal pengetahuan yang juga harus mengglobal lewat pendidikan (Tilaar, 1999:54-58). Jadi, pendidikan yang dapat menghasilkan manusia unggul dan dapat hidup dalam percaturan global, harus-lah pendidikan yang berkualitas yang mengembangkan seluruh potensi 
ruhani dan jasmani yang dimiliki manusia secara utuh dan imbang sejak usia dini. Dalam konteks pendidikan yang berkualitas, maka lembaga pendidikan dapat menjalankan salah satu fungsi dan tugasnya untuk menyiapkan tenaga kerja yang profesional dan trampil yang siap memasuki pasaran kerja secara kompetitif dalam pasar global. Selain itu, lembaga pendidikan juga harus men-jalankan tugas dan fungsi lain, berupa pengembang ilmu dan pewaris budaya kepada peserta didiknya. Lembaga pendidikan yang dapat menyiapkan manusia menjadi tenaga kerja profesional dan trampil, pengembang ilmu dan pewaris budaya, dan membangun kesadaran kolektif (Depdiknas,2006:15), memerlukan suatu kebijakan dan kemauan politik yang concern terhadap pendidikan.

Jika pendidikan dianggap sebagai sesuatu yang dapat menghasilkan tenaga kerja profesional yang siap memasuki pasar global, maka pendidikan harus dijadikan perioritas utama dalam pembangunan sumber daya manusia (Tilaar,1999:74;Depdiknas,2006:15).

Suatu bangsa yang memprioritaskan pendidikan dalam pembangunan sumber daya manusianya, ia akan menghasilkan manusia yang unggul sebagai tenaga kerja yang berkualitas kompetitif dan siap memasuki pasar kerja global. Upaya peningkatan kualitas sumber daya manusia pula yang ditempuh Taiwan, Irlandia, dan China serta negara-negara di kawasan Asia Tenggara. Begitu Taiwan berupaya menghapus buta sain dan membebaskan ujian masuk universitas, massa kritikal yang berpendidikan itu, kini berkembang pesat (Aristiarini,2006). Dengan demikian, maka prioritas pengembangan sumber daya manusia mestinya menjadi pilihan utama dalam pembangunan suatu bangsa, yang dimulai dari pendidikan anak usia dini sampai dengan perguruan tinggi yang tercermin dalam anggaran pendidikan. Anggaran pendidikan dalam APBN sebagai langkah nyata prioritas pengembangan SDM tidak termasuk gaji guru (Fuad, 2007, Kompas, 9 Maret;Depdiknas,2006).

Negara bangsa yang memprioritaskan pendidikan sebagai pembangunan sumber daya manusianya (SDM), menganggap bahwa melalui pendidikan akan memberikan kontribusi yang signifikan terhadap pertumbuhan ekonominya. Kualitas sumber daya manusia pada suatu negera-bangsa dapat dilihat dari indek pembangunan sumber daya manusia (HDI) sebagai suatu tolok ukur kemajuan dan keunggulan pendidikannya. Misalnya, Indonesia menempati rangking ke 111 dari 177 negara yang disurvey, dan terendah diatara negara-negara Asean, sedikit di atas Vietnam dengan rangking ke 112 (UNDP, 2004:141). Lain halnya dengan Irlandia, dalam waktu kurang dari satu generasi berhasil menjadi negara kaya di Eropa. Caranya, dengan menggratiskan sekolah menengah pada awal tahun 60-an. Dengan cara ini, Irlandia mencapai kemajuan sehingga anak anak kelas bawah secara ekonomis bisa mengakses pendidikan tinggi sejak tahun 1996. Sekarang ini, Irlandia telah menikmati hasilnya secara mencengangkan dan menakjubkan, terutama bagi negara-negara indistri maju.

Di Irlanidia, kini terdapat 10 perusahaan farmasi terbesar dunia memiliki industri di sana, 16 dari 20 industri perusahaan peralatan medis kaliber dunia juga ada di negara itu, dan tujuh dari sepuluh perusahan raksasa piranti lunak dunia ada di Irlandia (Aristiarini, 2006). Demikian hebatnya keunggulan manusia, jika manusia itu dijadikan investasi masa depan melalui akses pendidikan. Dengan memberikan kesempatan bagi seluruh anak bangsa untuk memperoleh pendidikan maka negara-bangsa itu akan menikamti hasilnya secara spektakuler.

Demikian juga China, pada tahun 1980-an telah melakukan seleksi para mahasiswa 
yang berbakat fisika dikirim ke luar negri melalui program yang dipelopori Tsung Dao Lee, peraih Nobel Fisika dari China. Kini China dalam waktu sepuluh tahun telah memiliki 915 mahasiswa program Doktor Fisika yang belajar di luar negeri (Aristiarini, 2006). Sekarang China tidak hanya mengirim maha-siswa program doktor Fisika ke luar negri, tetapi juga ribuan disiplin ilmu lain yang dikirim ke luar negri untuk program doktor. Sekarang kita dapat menyaksi-kan, bagaimana China menjadi suatu negara yang sangat maju pesat ekono-minya, sehingga negara industri maju lainya di dunia menjadi kedodoran meng-hadapinya. Berikut ini, akan digambarkan kondisi riil Indonesia berdasarkan HDI dibandingkan beberapa negara di Asia Tenggara, seperti dalam tabel 2 .

Tabel 2. Rangking Indonesia Berdasarkan HDI Dibandingkan Beberapa Negara Tahun 1995-2005

\begin{tabular}{|l|l|l|l|l|l|}
\hline & \multicolumn{5}{|c|}{ Tahun } \\
\cline { 2 - 6 } & $\begin{array}{l}199 \\
5\end{array}$ & $\begin{array}{l}200 \\
0\end{array}$ & $\begin{array}{l}200 \\
3\end{array}$ & $\begin{array}{l}200 \\
4\end{array}$ & $\begin{array}{l}200 \\
5\end{array}$ \\
\hline Thailand & 58 & 76 & 74 & 76 & 73 \\
\hline $\begin{array}{l}\text { Malaysi } \\
\text { a }\end{array}$ & 59 & 61 & 58 & 59 & 61 \\
\hline Philipina & 100 & 77 & 85 & 83 & 84 \\
\hline $\begin{array}{l}\text { Indones } \\
\text { ia }\end{array}$ & $\mathbf{1 0 4}$ & $\mathbf{1 0 9}$ & $\mathbf{1 1 2}$ & $\mathbf{1 1 1}$ & $\mathbf{1 1 0}$ \\
\hline Cina & 111 & 99 & 104 & 94 & 85 \\
\hline Vietnam & 120 & 108 & 109 & 112 & 108 \\
\hline
\end{tabular}

Sumber: Fasli Jalal (2005)

Dengan memperhatikan tabel 2 , menunjukkan bahwa Indonesia menempati urutan terendah dari enam negara di Asia Tenggara. Hal ini berarti bahwa pendidikan di Indonesia belum dijadikan perioritas dalam pembangun-an sumber daya manusianya. Oleh karenanya wajar Indonesia senantiasa ter-tinggal dalam berbagai hal, terutama rendahnya kualitas SDM. Hal ini sebagai akibat dari pendidikan tidak dimulai dari usia dini pada dekade akhir abad 20, sehingga
Indonesia tidak mampu berkompetisi dalam arena pasar kerja global.

Mencermati indikator HDI terutama menyangkut komitmen pemerintah dalam membiayai anggaran pendidikan baru mencapai $9.8 \%$ dari seluruh anggaran. Sementara anggaran pendidikan yang dikeluarkan pemerintah untuk semua level, pre-primery and primery school sebesar $37.8 \%$, scondary school $38.8 \%$ dan tertiary school 23.4\%, serta angka partisipasi kotor untuk ketiga level tersebut baru mencapai 65\% (UNDP, 2004:141174). Dengan memperhatikan indikator HDI tersebut, PAUD sebagai program dan pendidikan anak usia dini sebagai usaha awal dalam pengembangan SDM sebagai investasi masa depan, masih rendah. Bertalian dengan pengembangan SDM sebagai investasi masa depan, data menunjukkan bahwa, untuk Indonesia anak usia taman kanak-kanak (TK) baru terlayani sebanyak $25 \%$ dari populasi anak usia TK, dan hanya kurang $25 \%$ anak usia dini yang terlayani pendidikan dan pembinaan PAUD nonformal dari total populasi anak usia 2-6 tahun, yang berjumlah sekitar 28,12 juta anak (Kompas,13 Januari 2007; Dirjen PLS, 2006; Sudiyono, 2006).

Konsep tentang investasi sumber daya manusia yang dapat menunjang pertumbuhan ekonomi, sebenarnya telah dimulai sejak tahun 1960-an. Namun kondisi Indonesia pada kala itu belum sempat memikirkan pembangunan sumber daya manusia melalui investasi pendidikan. Kondisi masa itu sedang diterpa pergumulan politik dalam negeri antara nasionalis, komunis, dan agama. Kondisi terabaikannya pendidikan sebagai investasi sumber daya manusia berlanjut hingga runtuhnya pemerintahan Orde Baru dibawah kepemimpinan Suharto pada tahun 1998. Bahkan, hingga tahun 2006 belum terlihat secara serius bahwa pendidikan merupakan perioritas utama sebagai pembangunan sumber daya 
manusia. Buktinya, anggaran untuk pendidikan hanya $9,1 \%$ dari APBN tahun 2006 (Wisudo, 2006). Hal ini berarti pula bahwa pemerintah telah melanggar konstitusi yang mengharuskan biaya pendidikan sedikitnya $20 \%$ dari APBN/APBD.

Pendidikan sebagai investasi sumber daya manusia menurut Schult (1961) menegaskan bahwa pendidikan memberikan kontribusi lansung terhadap pertumbuhan dan pendapatan suatu negara, dan pentingnya pendidikan untuk menunjang ekonomi (Hicks, 1980; Wheeler, 1980). Melalui pendidikan akan terjadi peningkatan ketrampilan dan kemampuan produksi dari tenaga kerja yang terdidik. Sumbangan dari pendidikan sebagai investasi sember daya manusia menjadi semakin kuat setelah memperhitungkan efek interaksi antara pendidikan dan bentuk investasi fisik lainya (Psacharopoulos, 1984). Dalam konteks investasi, Schultz (1960) menegaskan bahwa ..."proses perolehan pengetahuan dan ketrampilan melalui pendidikan bukan merupakan suatu bentuk konsumsi semata-mata, akan tetapi juga merupakan suatu investasi”.

Hal ini berarti bahwa, pendidikan memiliki nilai ekonomis yang dapat dilihat sebagai tenaga kerja yang dapat menyumbang devisa negara. Namun, di pihak lain pendidikan juga memiliki nilai manusiawi yang memiliki karakter suatu bangsa sebagai penopang berdirinya suatu bangsa itu. Dengan demikian, pendidikan merupakan suatu proses investasi sumber daya manusia untuk melahirkan manusia yang unggul, profesional, dan kompetitif di masa depan. Pendidikan sebagai suatu bentuk investasi sumber daya manusia, setidak-nya harus memiliki tiga tujuan: sebagi suatu konsumsi, sebagai peningkatan pengetahuan dan ketrampilan, dan sebagai pemerataan memperoleh pendidikan. Dalam hal ini, Ace Suryadi (1993:25) menegaskan bahwa pendidikan sebagai suatu bentuk investasi sumber daya manusia bertujuan untuk: Pertama pendidi-kan ialah suatu bentuk konsumsi yang dapat memenuhi kepuasa seseorang untuk menikmati perolehan pengetahuan dan ketrampilan pada waktu sekarang.

$$
\text { Kedua, pendidikan dapat }
$$

membantu meningkatkan ketrampilan dan pe-ngetahuan untuk bekerja lebih produktif. Dengan pendidikan dan ketrampilan yang berkualitas dapat meningkatkan penghasilan tenaga kerja lulusan pendi-dikan di masa datang. Ketiga, di sisi lain pendidikan juga dapat memberikan pe-ngaruh terhadap pemerataan pendapatan masyarakat melalui pemerataan ke-sempatan memperoleh pendidikan. Dengan pendidikan yang dimiliki secara me-madai, seseorang memungkinkan untuk mendapatkan kesempatan dan akses ekonomi. Bahkan, berbagai akses kehidupan berpeluang besar dapat dicapainya.

Rendahnya pemahaman konsep tentang pendidikan sebagai investasi masa depan, yang menjadikan manusia sebagai bahan unggul dalam investasi itu, menjadi ciri para pejabat negara sejak dari pusat hingga daerah. Akhirnya, pengembangan sumber daya manusia Indonesia tidak terperhatikan secara baik (Aristiarini,2006). Hal ini bisa dilihat dari rendahnya standar pengajaran yang ma-sih buruk, kurangnya pelatihan dan kemampuan guru, rendahnya gaji guru, dan kurangnya pengembangan multi potensi anak sejak usia dini, bahkan terabaikan.

Padahal, potensi anak Indonesia jika dibina dengan serius sejak usia dini dalam berbagai hal memiliki kehadalan. Salah satu buktinya ialah dalam mengi-kuti berbagai event olipiade internasional. Misalnya, dalam bidang matematika, fisika, biologi, dan sain membuktikan kemampuan anak bangsa yang mengagumkan dengan perolehan berbagai medali, 
sejak tingkat dasar hingga menengah. Sayang sekali potensi ini belum dieksplorasi secara sistemik dan terintegrasi.

\section{c. Redisain Pendidikan di Indonesia}

Jika memperhatikan kondisi tenaga kerja dan tingkat keunggulan sumber daya manusia Indonesia sekarang, tentunya tidak bisa dikatakan sebagai kesa-lahan masa sekaranag, melainkan harus dirunut kronologisnya. Seperti telah di-singgung di bagian sebelumnya bahwa pendidikan di Indonesia belum dijadikan prioritas utama dalam pembangunan sumber daya manusia, sehingga kualitasnya senantiasa berada di urutan terbawah di antara negara-negera Asean. Agar pen-didikan di Indonesia dapat menghasilkan manusia yang berkualitas dalam meng-hadapi persaingan gelobal, perlu redisain secara menyeluruh, baik konten, mana-jemen, kelembagaan, biaya, kesinambungan sejak usia dini dan pengelolaannya.

Pendidikan yang dipersiapkan untuk melahirkan manusia Indonesia yang unggul di masa depan, memerlukan pengkajian ulang mengenai isi dan proses pendidikan itu sendiri. Oleh karena itu, pendidikan harus berisikan pengembangan potensi fithrah pikir, hati dan jiwa, rasa, serta raga. Dalam kaitan ini (Tilaar 1999:56) menyarankan bahwa manusia unggul itu herus mengembangkan sifatsifat networking, teamwork, dedikasi dan disiplin, jujur, inovatif, tekun, dan ulet. Manusia unggul perlu memiliki jaringan kerja yang luas, karena dunia sekarang ini tidak lagi tersekat oleh batas-batas negara, sehingga memerlukan manusia yang memiliki jaringan luas melampaui batas negara bahkan mendunia.

Untuk dapat menciptakan manusia yang memiliki jaringan kerja luas mengglobal, diperlukan kemampuan kerjasama dalam teamwork yang solid. Sebab masyarakat global sekarang ini memiliki kesempatan yang luas untuk mengembangkan keunggulan spesifik. Sumber daya manusia yang telah dikembangkan kemampuan spesifiknya akan membangun suatu teamwork (Harun: 2005) yang solid, yang pada gilirannya akan menghasilkan produk-produk unggul dalam pasar global dan dapat bersaing secara kompetitif. Industri-industri terkemuka di dunia kini telah mengembangkan teamwork yang solid sehingga mereka mampu menguasai pasar global dengan produk-produk berkualitas unggul, dan produk-produk itu semakin disempurnakan terus kualitasnya oleh sebab anggota-anggota teamwork-nya selalu meningkatkan kerjasama yang solid. Misalnya keunggulan Boeing, Microsoft (Lookatch, 1996; David \& Miller,1996; McCohan \& Lavelle,1998). Keberhasilan membangun jaring-an kerja yang luas mengglobal, bekerjasama dalam teamwork yang solid harus dibarengi dengan dedikasi dan disiplin. Manusia unggul memiliki ciri dan rasa pengabdian dan dedikasi yang tinggi terhadap pekerjaannya. Dia harus memiliki visi jauh ke depan (visioner) sebagai pengarah prinsip hidup (Tilaar, 1999:57). Visi yang idealis harus dijabarkan dalam berbagai kegiatan nyata secara strategik. Dalam pelaksanaan kegiatan itu diperlukan disiplin tinggi dengan target-target dan ukuran-ukuran pasti. Kesemuanya itu harus dikembangkan dalam isi dan proses pendidikan dalam bentuk nyata, dan dimulai sejak anak usia dini hingga masuk dunia persekolahan, sejak sekolah dasar sampai perguruan tinggi, dengan tatakelola dan akuntabilitas tinggi (Depdiknas,2006:38).

Manusia Indonesia yang unggul dengan ciri memiliki jaringan kerja luas, mampu membangun kerjasama dalam teamwork yang solid, berdedikasi dan berdisiplin tidak akan berhasil jika tidak didasari sifat jujur. Kejujuran merupakan sifat yang sangat penting, baik terhadap orang lain maupun terhadap diri sendiri. 
Terhadap orang lain manusia unggul haruslah dapat bekerjasama, karena pada akhirnya kerjasama berdasarkan saling percaya atau trust seperti yang diungkap oleh Fukuyama (1996) memungkinkan sesorang unggul akan survive. Kejujuran juga berhubungan dengan jujur terhadap kemampuan diri sendiri. Dalam hal ini Tilaar (1999:58) menyarankan bahwa kita harus jujur terhadap apa yang dapat diperbuat dan apa yang tidak dapat diperbuat, sebagai ciri sikap profesionalisme.

Manusia yang unggul juga harus memiliki sifat tekun, yaitu seseorang yang dapat memfokuskan perhatian pada tugas dan pekerjaan yang telah diserahkan kepadanya. Dengan ketekunan ia akan menghasilakan sesuatu, karena manusia yang unggul tidak akan pernah berhenti berpikir dan berbuat secara jujur sebelum ia mendapatkan hasil dengan kualitas yang maksimal. Hanya dengan ketekunanlah suatu produk akan dihasilkan dengan kualitas prima. Ketekunan yang dapat menghasilkan produk berkulitas juga harus disertai sifat ulet. Ulet artinya ia bekerja sungguh-sungguh untuk menghasilkan produk berkualitas. Ia tidak mudah putus asa sebelum produk itu dihasilkan, ia akan terus mencari dan mencari sampai mendapatkan hasil yang memuaskan. Jadi, pendidikan itu harus didesain ulang sehingga menghasilkan manusia unggul yang cerdas, jujur, tekun, ulet yang siap bekerja keras dan inovatif.

Pendidikan yang dapat menghasilkan manusia unggul seperti dipaparkan di atas, tidak dapat diperoleh dengan cara parsial, melainkan harus dilakukan dengan cara berkelanjutan sejak usia dini hingga akhir hayat. Pendidikan harus dimulai dari lingkungan keluarga, masyarakat yang bersifat informal, non formal, dan persekolahan yang bersifat formal. Oleh karenanya, pendidikan untuk menghasilkan manusia Indonesia unggul harus didesain ulang. Dalam hal ini, Tilaar (1999:45) menawarkan konsep dan strategi pengembangan pendidikan nasional sebagaimana tertuang dalam tabel 3 . Dengan memperhatikan konsep redisain pendidikan di Indonesia yang ditawarkan Tilaar dalam tabel 3, jelas bahwa pendidikan yang berorientasi pada penciptaan sumber daya manusia unggul masih jauh dari kenyataan. Sebab masih sangat banyak persoalan pendidikan yang harus diatasi dan direalisasikan sebagai upaya peningkatan sumber daya manusia Indonesia unggul. Namun demikian, sudah ada upaya pemerintah dalam rangka merubah dan mendisain ulang pendidikan di Indonesia yang mulai dilakukan secara konstitusional.

Tabel 3 Peta Permasalahan Pendidikan dewasa ini serta Rencana Strategis Pengembangan Sistem Pendidikan dan Pelatihan Nasional Menapaki Abad 21

\begin{tabular}{|c|c|c|}
\hline Masalah pendidikan Dewasa ini & Visi Strategis Sistem Diklatnas & Rencana Strategis Sitem Diklatnas \\
\hline $\begin{array}{l}\text { Menurunnya akhlak dan moral } \\
\text { peserta didi. }\end{array}$ & $\begin{array}{l}\text { Manusia yang sadar dan cinta ip- } \\
\text { tek, manusia yang berbudaya ber- } \\
\text { moral serta berwawasan kebang- } \\
\text { saan yang sehat dengan mene- } \\
\text { kankan pada persatuan bangsa. }\end{array}$ & $\begin{array}{l}\text { Lembaga lembaga pendidikan: } \\
\text { keluarga, LSM, sekolah (formal } \\
\text { dan nonformal) sebagai pusat } \\
\text { pengem-bangan disiplin, akhlak } \\
\text { yang terpuji dan etika praktis. }\end{array}$ \\
\hline $\begin{array}{l}\text { Pemerataan kesempatan } \\
\text { memperoleh pendidikan dan } \\
\text { pemerataan kualitas pendidikan. }\end{array}$ & $\begin{array}{l}\text { Pendidikan yang berorientasi } \\
\text { keunggul an tanpa mengabaikan } \\
\text { pembentukan kemampuan intelek- } \\
\text { tual bangsa, sehingga dapat ber- } \\
\text { saing dengan bangsa bangsa di } \\
\text { kawasan ASEAN dan di kawasan } \\
\text { pasifik. }\end{array}$ & $\begin{array}{l}\text { Penuntasan Wajar } 9 \text { tahun dan } \\
\text { perin-tisan Wajar } 12 \text { tahun di } \\
\text { beberapa daereah. } \\
\text { Pemerataan kualitas pendidikan. }\end{array}$ \\
\hline 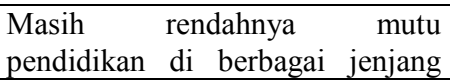 & $\begin{array}{l}\text { Menciptakan sistem pendidikan } \\
\text { yang berwawasan mutu dengan }\end{array}$ & $\begin{array}{l}\text { Kualitas pendidikan dengan stan- } \\
\text { dard ASEAN untuk IPA, Matema- }\end{array}$ \\
\hline
\end{tabular}




\begin{tabular}{|c|c|c|}
\hline dan jenis pendidikan. & peran serta masyarakat. & $\begin{array}{l}\text { tika, Bahasa (Inggris, Cina, } \\
\text { Jepang). } \\
\text { Penuntasan struktur LPTK dengan } \\
\text { dasar akademik kuat. }\end{array}$ \\
\hline $\begin{array}{l}\text { Masih rendahnya efisiensi internal } \\
\text { sistem pendidikan. }\end{array}$ & $\begin{array}{l}\text { Pengelolaan organisasi pendidikan } \\
\text { secara "Bussiness like" sehingga } \\
\text { dinamis, efissien, serta } \\
\text { mengurangi pemborosan dalam } \\
\text { investasi sektor pendidikan. }\end{array}$ & $\begin{array}{l}\text { Meningkatkan pengelolaan } \\
\text { internal dengan penerapan dasar- } \\
\text { dasar TQM dan ISO 9000. } \\
\text { Otonomi Universitas dalam } \\
\text { penge-lola an sumber dan } \\
\text { kurikulum. }\end{array}$ \\
\hline $\begin{array}{lcr}\text { Masih } & \text { rendahnya } & \text { efisiensi } \\
\text { eksternal } & \text { sistem } & \text { pendidikan } \\
\text { (relevansi yang rendah) }\end{array}$ & $\begin{array}{l}\text { Orientasi pendidikan kepada } \\
\text { kebutuh-an masyarakat (dunia } \\
\text { industri dan dunia usaha serta } \\
\text { pengembangan dan penerapan } \\
\text { iptek) tanpa terjebak pada } \\
\text { sekilaritas dan konsumerisme. }\end{array}$ & $\begin{array}{l}\text { Kemitraan dengan dunia usaha } \\
\text { dan industri dalam riset pengem- } \\
\text { bangan kurikulum. } \\
\text { Pengembangan sikap wirausah. } \\
\text { Perluasan Politeknik dan pusat- } \\
\text { pusat penelitian. }\end{array}$ \\
\hline $\begin{array}{l}\text { Kelembagaan pendidikan dan } \\
\text { pela-tihan yang kaku dan belum } \\
\text { jelas arah }\end{array}$ & $\begin{array}{l}\text { Ketertautan antara pendidikan dan } \\
\text { pelatihan yang kontinum dengan } \\
\text { peran serta dunia industri dan } \\
\text { pengembang-an sikap wirausah. }\end{array}$ & $\begin{array}{l}\text { Menetapkan tugas pendidikan } \\
\text { pelatih-an dan peran serta dunia } \\
\text { usaha (industri) yang jelas. } \\
\text { Masyarakat industri/dunia usaha } \\
\text { se-makin memegang peran } \\
\text { penting dalam pelatihan }\end{array}$ \\
\hline $\begin{array}{l}\text { Manajemen pendidikan dan } \\
\text { pelati-han nasional yang belum } \\
\text { sejalan dengan manajemen } \\
\text { pembangunan nasional }\end{array}$ & $\begin{array}{l}\text { Disentralisasi pengelolaan kepada } \\
\text { daerah dengan perioritas pada } \\
\text { penyiapan tenaga kerja yang } \\
\text { diperlu-kan oleh pembangunan } \\
\text { daerah dalam rangka } \\
\text { pembangunan nasional serta } \\
\text { kerjasama sub-regional, regional } \\
\text { dan kawasan Asia pasifik. }\end{array}$ & 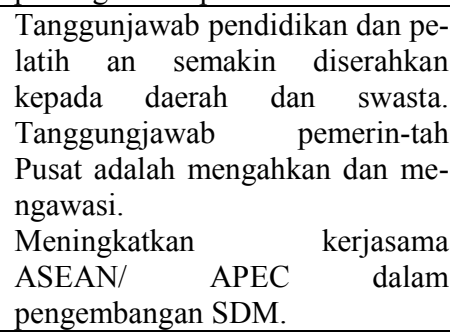 \\
\hline SDM yang belum profesional & $\begin{array}{l}\text { Pengembangan SDM pengelola } \\
\text { serta tenaga teknis kependidikan } \\
\text { yang profesional di semua dan } \\
\text { jenis pendidikan. }\end{array}$ & $\begin{array}{l}\text { Peningkatan mutu LPTK dan } \\
\text { pusat- pusat pendidikan. } \\
\text { Pengembangan program pendidi- } \\
\text { kan dan pelatihan manajer- } \\
\text { manajer dalam berbagai tingkatan. }\end{array}$ \\
\hline
\end{tabular}

Sumber: Diadopsi dari Tilaar (1999:45) Beberapa agenda reformasi pendidikan nasional.

Misalnya dengan lahirnya Undang-Undang SISDIKNAS nomor 20 tahun 2003, Undang-Undang Nomor 14 tahun 2005 tentang Guru dan Dosen, PP. Nomor 18 tahun 2007 tentang sertifikasi guru serta berbagai peraturan perundangundangan yang bertalian dengannya. Masih dalam konteks rediasain pendidikan di Indonesia, Depdiknas (2000) telah melakukan workshop dalam rangka pengkajian dan perumusan filosofi, kebijakan dan strategi pendidikan nasional yang ditawarkan, sebagaimana penulis rangkum dalam deskripsi yang tertuang dalam tabel 4. Mengacu pada tabel 4 tersebut yang merupakan kebijakan dan strategi pendidikan nasional, jelas tampak bahwa keinginan untuk melahirkan manusia Indonesia unggul yang mampu berkompetisi dalam percaturan pasar global, tampak tegas dan serius. Bahkan, keinginan itu tidak hanya bersifat parsial, melainkan dimulai dari sejak 
pendidikan usia dini sudah harus menjadi perhatian pemerintah yang dituangkan dalam Renstra Depdiknas 2006. Misalnya dengan kebijakan 8 akses program PAUD, yang diarahkan untuk memberikan dukungan terselenggaranya pelayanan PAUD yang bermutu baik jalur formal seperti TK/RA maupun jalur nonformal seperti KB,TPA dan bentuk lain yang sejenis (Depdiknas, 2006:32,48). Dengan demikian, pendidikan di Indonesia kini sudah jelas arah dan sasarannya, PAUD hingga perguruan tinggi, tinggal upaya merealisasikan kebijakan yang strategis itu ke dalam bentuk tindakan nyata. Tindakan nyata ini setidaknya direalisasikan dalam bentuk pemenuhan anggaran pendidikan minimal $20 \%$ dari APBN/APBD, yang telah diamanatkan secara konstitusional.

\section{d. Pendidikan Untuk Semua}

Pendidikan merupakan hak mendasar yang harus diterima oleh setiap warga negara. Konstitusi telah mengamanatkan bahwa negara mempunyai kewajiban untuk mencerdaskan seluruh warganya lewat pendidikan. Pendidikan yang harus diterima oleh warganya itu memberikan peluang bagi setiap warga negara dimulai dari pendidikan anak usia dini sampai perguruan tinggi. Dengan demikian, pendidikan itu harus diselenggarakan oleh negara untuk semua kelompok umur termasuk anak usia dini, penyandang cacat, masyarakat terpencil dan kaum wanita, dan anakanak dengan bakat khusus (Depdiknas, 2000).

Tabel 4. Pilosofi, Kebijakan dan Strategi Pendidikan Nasional

\begin{tabular}{|c|c|c|}
\hline ndidikan Nasional & Kebijakan Pendidikan Nasional & Pendidikan Nasional \\
\hline $\begin{array}{l}\text { - Pendidikan sebagai sistem } \\
\text { merupakan sistem terbuka yang } \\
\text { senantiasa berintegrasi dengan } \\
\text { lingkungannya. } \\
\text { - Pendidikan bersifat progresif, } \\
\text { tidak resisten terhadap } \\
\text { perubahan, mampu mengen- } \\
\text { dalikan arahperubahan. } \\
\text { - Pendidikan harus mampu meng- } \\
\text { hasilkan produk-produk yang } \\
\text { dibutuhkan oleh perubahan } \\
\text { - Layanan pendidikan yang di- } \\
\text { berikan umum dan spesifik. } \\
\text { Untuk kelompok usia anak- } \\
\text { Layanan pendidikan yang }\end{array}$ & $\begin{array}{l}\text { - Pemberdayaan masyarakat: } \\
\text { pengembangan kesadaran tung- } \\
\text { gal dalam kemajemukan, } \\
\text { enrichment berkelnjutan, afir- } \\
\text { matif policy. } \\
\text { - Pemberdayaan pendidikan: } \\
\text { negeri dan swasta, pendanaan } \\
\text { pendidikan } \\
\text { - Desentralisasi/Otonomi: arti de- } \\
\text { sentralisasi, dimensi politik dan } \\
\text { budaya, ragam desentralisasi, ke } \\
\text { bijakan kurikuler, biaya pendidi } \\
\text { kan dari keluarga, masyarkat, } \\
\text { pemerintah, manajemen karir } \\
\text { guru. }\end{array}$ & $\begin{array}{l}\text { - Kelompok-kelompok sasaran } \\
\text { spesifik: anak usia dini, } \\
\text { keluarga, penyandang cacat dan } \\
\text { kelainan, kelompok kurang } \\
\text { beruntung, anak berbakat, } \\
\text { wanita, masyarakat terpencil, } \\
\text { kelompok usia produktif, lanjut } \\
\text { usia. } \\
\text { - Deokratisasi pendidikan: perlua- } \\
\text { san dan pemerataan kesempatan } \\
\text { pendidikan, pendidikan populis } \\
\text { dan universal, pemberdayaan } \\
\text { dan pendayagunaan berbagai in- } \\
\text { stitusi masyarakat, pengakuan } \\
\text { hak-hak masyarakat termasuk }\end{array}$ \\
\hline
\end{tabular}




\begin{tabular}{|c|c|c|}
\hline $\begin{array}{l}\text { diberikan umum dan spesifik. } \\
\text { Untuk kelompok usia anak } \\
\text { berbeda dengan remaja dan } \\
\text { dewasa, daerah perkoptaan } \\
\text { berbeda dengan pedesaan dan } \\
\text { terpencil, termasuk perlu } \\
\text { perlakuan khusus untuk } \\
\text { kelompok ekonomi lemah, } \\
\text { kelompok berkelainan fisik dan } \\
\text { mental } \\
\text { - Pluralisme dalam pendidikan } \\
\text { nasional perlu menjadi acuan. }\end{array}$ & $\begin{array}{l}\text { - Relevansi kurikulum pendidi- } \\
\text { kan: penuntasan wajar dikdas, } \\
\text { pendidikan berorientasi pemenu } \\
\text { han kebutuhan tenaga kerja dan } \\
\text { pembangunan ekonomi, prog- } \\
\text { ram visioner untuk mencapai ke } \\
\text { unggulan dan perkembangan ip- } \\
\text { teks, pendidikan moral dan ka- } \\
\text { rakter bangsa, penekanan pendi- } \\
\text { dikan untuk kesejahteraan ma- } \\
\text { syarakat. } \\
\text { - Akuntabilitas institusi: jaminan } \\
\text { kualitas, aspek legal akuntabili- } \\
\text { tas. }\end{array}$ & $\begin{array}{l}\text { hak pendidikan, kerjasama deng } \\
\text { an industri. } \\
\text { - Pengembangan kapabilitas: } \\
\text { pengurangan ketergantungan } \\
\text { pendidikan pada pemerintah, } \\
\text { penyelenggaraan pendidikan se- } \\
\text { cara demokratis, akuntable dan } \\
\text { bermutu, kurikulum yang menja } \\
\text { min terjadinya pembentukan ke- } \\
\text { pribadian dan profesionalitas, pe } \\
\text { nerapan metode konstruktivis. } \\
\text { - Desentralisasi pendidikan: pe- } \\
\text { ngaturan perimbangan keuangan } \\
\text { pusat dan daerah, manajemen } \\
\text { pertisipatif keluarga-masyarakat } \\
\text { dan dunia uasaha/industri dalam } \\
\text { pendidikan, pemberdayaan } \\
\text { pemerintah daerah. } \\
\text { - Muatan strategis: penguatan pen } \\
\text { didikan ketram,pilan dasar, pe- } \\
\text { nguasaan kompetensi generik, } \\
\text { penyelenggaraan prodi dengan } \\
\text { kualitas yang marketable, pendi- } \\
\text { dikan iptek, pendidikan budi } \\
\text { pekerti moral dan agama, pendi- } \\
\text { dikan multi kultural dan perda- } \\
\text { maian. } \\
\text { - Akuntabilitas pendidikan: pene- } \\
\text { rapan TQM dalam pendidikan } \\
\text { secara konsisten, optimalisasi } \\
\text { kinerja badan akreditasi pendi- } \\
\text { dikan yang profesional, penega- } \\
\text { kan legalitas untuk tegaknya } \\
\text { proses pendidikan, penerapan } \\
\text { sistem karir dan kesejahteraan } \\
\text { tenaga pendidikan, penerapan } \\
\text { profesionalitas manajemen } \\
\text { pendidikan. }\end{array}$ \\
\hline
\end{tabular}

Sumber: Diadaptasi dari Depdiknas (2000) Naskah workshor 16 Pebruari 2000 di Hotel Santika Yogyakarta

Tentang Filosofi, Kebijakan dan Strategi Pendidikan Nasional

\section{Berbicara}

masalah

pendidikan di Indonesia, ternyata hak dasar warga negara untuk mendapat pendidikan sejak usia dini sampai pendidikan dasar saja masih belum terpenuhi. Padahal, Perserikatan Bangsan-Bangsa telah mendorong semua negara berkembang untuk memperhatikan kesempatan memperoleh pendidikan ini dengan semboyan education for all dijadikan sebagai perioritas kebijakan yang harus dilaksanakan oleh pemerintahan masing masing negara (Harun,1997:2), termasuk AUD. Dalam kaitan ini, Winarno Surakhmad (Kompas, 2006) menegaskan perioritas pencerdasan bangsa merupakan amanat konstitusi. Oleh karena itu, layanan pendidikan usia dini dan pendidikan dasar serta pendidikan lanjutan yang berkualitas harus menjadi agenda utama 
pembangunan pemerintah. Pendidikan juga merupakan masalah publik yang harus dipikirkan oleh semua komponen bangsa. Dalam kaitan ini, Utomo Dananjaya (Kompas, 2006) menegaskan bahwa persoalan pendidikan sangat mendasar dalam kehidu-pan bernegara, karena pendidikan itu terkait erat dengan hak dasar warga negara, Nina (Kompas,2007) dan kewajiban negara dalam pelaksanaan pemba-ngunan yang terintegrasikan yang terpadu dalam satu kebijakan yang terukur.

Wacana pendidikan sebagai hak mendasar setiap warga negara memang menarik untuk didiskusikan. Sebab kenyataannya masih banyak warga negara yang belum dapat menikmati haknya itu. Dalam kaitan ini UNSECO (2001) melaporklan bahwa, sekitar 100 juta anak usia sekolah dari sekitar 300 juta anak usia sekolah, belum mendapatkan kesempatan pendidikan. Sebanyak $60 \%$ dari jumlah tersebut adalah anak perempuan. Oleh karena itu UNESCO (2001) telah mencanangkan program anak usia sekolah ini harus tuntas pada tahun 2015 untuk mendapatkan akses pendidikan dasar, terutama di 32 negara yang riskan kekeringan dan kelaparan. Program UNESCO juga telah menyepakati untuk mencanangkan pelaksanaan program pendidikan anak usia dini menjadi peroritas dalam pembangunan program pendidikan di setiap negara anggota. Sementara itu, World Education Forum, di Dakar Sinegal, pada bulan April 2000 mentepkan framework untuk mencapai empat tujuan pengembangan pendidikan.
Pengembangan itu ialah (UNESCO, 2001): program pendidikan usia dini secara komprehensif, keberlangsungan program wajib belajar pendidikan dasar, program pelatihan life-skill untuk remaja dan dewasa, serta program mengatasi kesenjangan memperoleh pendidikan antara peria dan wanita.

\section{PENUTUP}

Mendiskusikan persoalan pendidikan yang berkualitas, tidak mungkin dipotong di tengah keberlangsungannya proses pendidikan, melainkan harus dimulai sejak anak usia dini. Sebab pendidikan anak usia dini sebagai pendidikan yang sangat fundamental dan diakui secara internasional (Dirjen PLS, 2006). Oleh karena itu, anak usia dini juga memiliki hak yang sangat mendasar untuk mendapatkan pendidikan sebagai peletak dasar bagi perkembangan dan pertumbuhan anak selanjutnya. Sebagimana diprogramkan lembaga UNESCO, bahwa pendidikan anak usia dini haruslah menjadi perioritas dan perhatian pemerintah dan negara, jika negara tersebut menginginkan warganya memiliki keunggulan komparatif dan kompetitif dalam percaturan global. Oleh karena itu, manajemen, anggaran, sumberdaya manusia, dan sarana pendidikan anak usia dini harus menjadi tanggungjawab negara dan pemerintah untuk memenuhinya, sebagai realisasi dari pelaksanaan amanat konstitusi. Selain itu, konsep dan implementasi pendidikan anak usia dini harus dikembalikan kepada jalur yang benar. Jalur yang benar itu ialah bahwa pendidikan anak usia 
dini merupakan usaha membantu memfasilitasi anak untuk berkembang sesuai dengan umur dan potensi masing-masing anak yang mereka miliki (Sukiman,2006; Sudiyono,2006; Depdiknas,2006:30). Pembelajaran dalam pendidikan anak usia dini ialah yang dirancang secara terintegrasi dalam bermain sebagai dunia mereka (Dirjen PLS, 2006), sehingga potensi mereka dapat berkembang secara optimal sesuai dengan tahap perkembangan dan usia mereka (Depdiknas, 2006:48). Jadi, semua kegiatan dan aktivitas anak usia dini dalam pengembangan sensori dan persepsi, motorik kasar dan halus, sosial dan emosional, kognitif dan bahasa dilakukan melalui bermain. Sebab bermain merupakan gambaran motivasi intrinsik yang dimiliki anak, seperti dikatakan Seifert and Hoffnung (1997:392) bahwa ..."children at play generally show intrinsic motivation". Pendek kata, pendidikan anak usia dini merupakan bagian yang terpenting dalam meletakkan dasar pengembangan multiple intelligences yang dimiliki anak, sebagai landasan bagi pertumbuhan dan perkembangan anak untuk masa depan mereka (Sudiyono, 2006). Meskipun sampai akhir tahun 2000 kita kurang peduli (Dirjen PLS, 2006).

Pembelajaran bagi pendidikan anak usia dini dan taman kanak-kanak ialah pembelajaran yang harus dirancang dalam berbagai bentuk dan jenis per-mainan yang menyenangkan mereka. Dengan bermain, diharapkan akan tumbuh kembang secara optimal potensi yang mereka miliki, seperti potensi moral dan nilai-nilai agama, sosial, emosional, kemandirian, bahasa, kognitif-logika, fisik motorik, dan seni (Depdiknas,2005:3). Oleh karenanya,disain dan pengembangan model assessment dan model bermain untuk mencapai tingkat perkembangan kemampuan bahasa,kognitif dan motorik menjadi fokus penelitian disertasi ini.

\section{DAFTAR PUSTAKA}

$\begin{array}{ccr}\text { Al-Qur'an Al Karim } & \text { dan } \\ \text { Terjemahan, }(1411 & \mathrm{H}) \text {. } \\ \text { Mujamma' Khadim } & \text { Al } \\ \text { Haramain al Malik al Fahd. } & \text { Madinah Munawwarah. }\end{array}$

Aristiarini Agnes. (2006).

Membangun Keindonesiaan baru: Sewindu Reformasi mencari visi Indonesia 2030. Kompas, 19 Mei 2006.

Aristiarini Agnes. (2006). Membangun Keindonesiaan baru: Sewindu Reformasi mencari visi Indonesia 2030. Kompas, 19 Mei 2006.

Depdiknas. (2000). Filosofi, Kebijakan dan Strategi Pendidikan Nasional, Naskah Workshop, 16 Pebruari, Yogyakarta: Hotel Santika

(2005). Pedoman pengembangan silabus di Taman kanak-kanak. Jakarta: Ditjen. Manajemen Pendidikan Dasar dan Menengah. . (2006). Pendidikan anak usia dini: "Kembali kepada bermain". Makalah disampaikan pada sarasehan Guru Taman Kanak-kaka TKABA Pimpinan Dearah 
Aisyiyah Kota Yogyakarta tanggal 9 dan 16 Desember 2006.

(2007). Naskah Akademik $P G-P A U D$. Jakarta: Dtjen Dikti Depdiknas.

(2006). Renstra Depdiknas 2005-2010. Jakarta: Depdiknas.

(2006). Rencana peraturan pemerintah tentang Pendidikan Anak Usia Dini. Jakarta:Ditjen Dikti, diakses tanggal 10 Maret 2006 dari. http://www.yahoo.dikti.org.

Dirjen PLS. (2006). Kebijakan pemerintah dalam pembinaan anak usia dini (PAUD). Makalah disampaikan dalam seminar nasional pemberdayaan masyarakat dan keluarga dalam penyelenggaraan program pendidikan anak usia dini (PAUD) di Universitas Negeri Semarang, tanggal 4 Desember 2006.

Fasli Jalal.(2004).Arah kebijakan nasional pendidikan anak usia dini (jalur pendi-dikan nonformal),Buletin $P A D U$, Ditjen Diklusepa, Edisi khusus, (39-44).

Fuad Hassan. (1998). Bermain Sebagai Hak Anak, Makalah dalam seminar sehari "Early Childhood Education" 24 September 1998. Yogyakarta: IKIP Yogyakarta.

Harun Rasyid (1997). Determinan pemerataan kesempatan memperoleh pendidikan SLTP bagi anak usia 13-15 tahun di daerah perbatasan Kalimantan Barat- Sarawak
Malaysia, Tesis, Yogyakarta: PPs IKIP.

Kompas. (2005). Pendidikan Anak Usia Dini, Jangan hanya Dinikmati Anak Orang Kaya, Selasa 19 Juli 2005.

Kompas. (2006). Pendidikan TK: Pembelajaran tematik solusi bagi kelas awal. Tanggal 15 Juni 2006.

Kompas. (2007). Tingkatkan investasi pada pengembangan anak usia dini. Tanggal 13 Januari 2007.

Papalia, E. Diane \& Olds, W. Saaly. (1986). Human development. Third edition. New York: McGraw-Hill book Company.

Papalia, E. Diane \& Olds, W. Saaly. (2001). Human development. eight edition. New York: McGraw-Hill book Company.

Piaget, Jean. (1974). The Construction of Reality in the Child, New York: Ballantine Books.

Purba, Sanaha Yohanes. (2007). Aku takut ke sekolah. Kompas 19 Pebruari 2007

Reodiger III, L. Henry; Rusthon, Philippe J.; Capldi, D. Elizabeth; Paris, G. Scott. (tt). Psychology. Toronto: Little E. Brown and Comapany.

Sudijono Sastroatmodjo. (2006). Pemberdayaan peran serta masyarakat dalam program pendidikan anak usia dini. Makalah disampaikan dalam seminar nasional pemberdayaan masyarakat dan keluarga dalam penyelenggaraan program pendidikan anak usia dini. 
Sukiman dan M. Nuch Rahardjo.

(2004). Seri contoh

Pembelajaran PAUD untuk anak usia 2-6 tahun Bidang Warna. Jakarta: Direktorat PAUD Ditjen PLSP Depdiknas.

Sukiman. (2006). Kebijakan Ditjen PLS dalam akses layanan PAUD yang mudah, murah, dan bermutu. Makalah disampaikan dalam seminar nasional pemberdayaan masyarakat dan keluarga dalam penyelenggaraan program pendidikan anak usia dini (PAUD) di Universitas Negeri Semarang, tanggal 4 Desember 2006.

Tilaar, HAR, (1999). Beberapa Agenda Reformasi Pendidikan Nasional : Dalam Perspektif Abad 21, Magelang : Indonesia Tera.

UNDP. (2004). Human Development Report, New York: UNDP Wismiarti. (2004). Pendidikan Anak Usia Dini Berbasis Kecerdasan Jamak di Sekolah Al-Falah, Buletin PADU, Ditjen Diklusepa, Edisi khusus, (39-44). 